\title{
Penanganan edentulus total rahang atas yang dengan disertai denture-induced hyperplasia Management of total maxillary edentulous with denture-induced hyperplasia
}

\author{
Elizabeth Mailoa, Peter Rovani, Edy Machmud \\ Bagian Prostodonsia \\ Fakultas Kedokteran Gigi Universitas Hasanuddin \\ Makassar, Indonesia
}

\section{ABSTRACT}

Lesions caused by traumatic or unbalance occlusion, and overextension denture may occur in the majority of patients who use denture. This generally occurs in the use of unfit full dentures (FD) and in a long period of time causing chronic irritation to mucosal tissues caused by the sharp and overextension of the FD flange. One of the most common tissue reaction caused by using unfit FD is inflammatory fibrous hyperplasia or more commonly known as the flabby ridge. This tissue reaction appears as fold of mucosal tissue, single or multiple, grow excessively around the sulcus mucobuccal, on the mucosa area unite gingiva and the cheek mucosa. Movement and growth of the tissue continuously causes problems in maintaining retention of FD. This article reports the management of denture-induced hyperplasia on maxilla edentulous of a 65-year old woman. Hyperplasia occurred from the left premolar to right premolar region of the maxilla. Excision was carried out through a $7 \mathrm{~cm}$ length tissue and then made for a conventional FD. As the result, patients are satisfied with the use of the new FD and did not feel any further disruption to mucosal tissues.

Key words: flabby ridge, inflammatory fibrous hyperplasia, denture-induced hyperplasia

\begin{abstract}
ABSTRAK
Lesi traumatik yang disebabkan oleh gigitiruan dengan oklusi yang berlebihan atau tidak seimbang dapat terjadi pada sebagian besar pasien yang menggunakan gigitiruan. Hal ini umumnya terjadi pada pemakaian gigitiruan penuh (GTP) dengan kondisi yang longgar dan dalam jangka waktu yang lama sehingga menyebabkan iritasi kronis pada jaringan mukosa akibat sayap gigitiruan yang tajam atau kepanjangan. Salah satu reaksi jaringan paling umum akibat pemakaian GTP yang longgar adalah inflamasi hiperplasia fibrosa atau lebih dikenal sebagai flabby ridge. Reaksi jaringan ini tampak berupa lipatan jaringan mukosa yang tunggal atau jamak, bertumbuh secara berlebihan sekitar sulkus mukobukal, yaitu pada daerah pertemuan gingiva dan bagian dalam pipi. Pergerakan dan pertumbuhan jaringan yang berkelanjutan dapat menimbulkan masalah dalam mempertahankan retensi gigitiruan. Dalam artikel ini dilaporkan tentang penanganan kasus denture-induced hyperplasia pada edentulus total rahang atas seorang pasien wanita usia 65 tahun. Hiperplasia terjadi mulai dari regio premolar kiri sampai premolar kanan rahang atas. Penanganan kasus ini dilakukan melalui eksisi jaringan sepanjang $7 \mathrm{~cm}$ kemudian dibuatkan GTP secara konvensional. Hasilnya, pasien puas dengan penggunaan GTP yang baru dan tidak merasa ada gangguan lagi pada jaringan mukosa.
\end{abstract}

Kata kunci: flabby ridge, peradangan hiperplasia fibrosa, denture-induced hyperplasia

Koresponden: Elizabeth Mailoa, Bagian Prostodonsia Fakultas Kedokteran Gigi, Universitas Hasanuddin. Jl. Kandea No.5, Makassar. E-mail: elsma@indosat.net.id 